\title{
Prognostic significance of overexpression of c-Met oncoprotein in cholangiocarcinoma
}

\author{
M Miyamoto ${ }^{1,2}$, H Ojima ${ }^{3}$, M Iwasaki ${ }^{4}$, H Shimizu', A Kokubu', N Hiraoka ${ }^{3}$, T Kosuge ${ }^{5}$, D Yoshikawa ${ }^{2}$, T Kono ${ }^{2}$, \\ H Furukawa ${ }^{2}$ and T Shibata* ${ }^{*, 1,3}$
}

'Division of Cancer Genomics, National Cancer Center Research Institute, 5-I - I, Tsukiji, Chuo-ku, Tokyo 104-0045, Japan; ${ }^{2}$ Division of Gastroenterologic and General Surgery, Department of Surgery, Asahikawa Medical College, Asahikawa, Japan; ${ }^{3}$ Division of Molecular Pathology, National Cancer Center Research Institute, Tokyo, Japan; ${ }^{4}$ Epidemiology and Prevention Division, Research Center for Cancer Prevention and Screening, National Cancer Center, Tokyo, Japan; ${ }^{5}$ Hepatobiliary and Pancreatic Surgery Division, National Cancer Center Hospital, Tokyo, Japan

BACKGROUND: Cholangiocarcinoma (CC) is a highly malignant carcinoma. We attempted to clarify the prognostic significance of c-Met overexpression and its association with clinicopathological factors in patients with CC.

PATIENTS AND METHODS: One hundred and eleven patients with intrahepatic CC (IHCC) and I36 patients with extrahepatic CC (EHCC) who had undergone curative surgery were divided immunohistologically into c-Met ${ }^{\text {high }}$ and c-Met ${ }^{\text {low }}$ groups. Clinicopathological factors and outcomes were compared between the groups. c-Met and epidermal growth factor receptor (EGFR) expression was also examined in $10 \mathrm{CC}$ cell lines.

RESULTS: The positivity of c-Met was 45.0\% in IHCC and 68.4\% in EHCC; c-Met ${ }^{\text {high }}$ expression was demonstrated in II.7\% of IHCC and $16.2 \%$ of EHCC. C-Met ${ }^{\text {high }}$ expression was significantly correlated with the 5 -year survival rate for CC overall $(P=0.0046)$ and for IHCC $(P=0.0013)$, histopathological classification in EHCC, and for EGFR overexpression in both IHCC and EHCC. Coexpression and coactivation of c-Met and EGFR were also observed in CC cell lines. Multivariate analysis revealed that c-Met ${ }^{\text {high }}$ expression was an independent predictor of poor overall and disease-free survival in patients with IHCC.

CONCLUSIONS: C-Met overexpression is associated with EGFR expression and is a poor prognostic factor in CC.

British Journal of Cancer (201 I) 105, I31-138. doi:10.1038/bjc.201 I.199 www.bjcancer.com

Published online 14 June 2011

(c) 201I Cancer Research UK

Keywords: c-Met; cholangiocarcinoma; immunohistochemistry; prognostic factor; epidermal growth factor receptor

Cholangiocarcinoma (CC) is a highly malignant invasive carcinoma arising through malignant transformation of cholangiocytes. Epidemiologic studies have demonstrated that the incidence and mortality rates of this disease, especially those of intrahepatic CC (IHCC), are increasing worldwide (Mouzas et al, 2002; Okuda et al, 2002; Blechacz and Gores, 2008; Hezel and Zhu, 2008; Yachimski and Pratt, 2008; Aljiffry et al, 2009).

It is difficult to diagnose CC at an early stage because of the lack of clinical symptoms at this point, and most patients have unresectable disease at clinical presentation. Surgical resection is the only curative therapy, but among those patients who receive it, recurrence rates are high (Hezel and Zhu, 2008). To date, no randomised study has demonstrated any clear survival benefit of a specific chemotherapeutic regimen for cases of unresectable and recurrent CC (Aljiffry et al, 2009). Existing phase II data and a more recent meta-analysis suggest that gemcitabine and gemcitabine-based platinum regimens offer a slight advantage over other regimens (Hezel and $\mathrm{Zhu}, 2008$ ).

Recently, a new treatment strategy for CC has been proposed, in the light of better understanding of the molecular mechanisms of carcinogenesis: it has been proposed that receptor tyrosine kinases

*Correspondence: Dr T Shibata; E-mail: tashibat@ncc.go.jp

Received 17 December 2010; revised 4 May 20II; accepted II May 201 I; published online 14 June 201 I
(RTKs), such as epidermal growth factor receptor (EGFR), vascular epithelial growth factor (VEGF) and c-Met, are promising targets for treatment of CC (Socoteanu et al, 2008; Yoshikawa et al, 2008). In a previous report, we have indicated that EGFR and VEGF could be promising molecules for targeted therapy of CC (Yoshikawa et al, 2008, 2009).

c-Met, also known as scatter factor, is a high-affinity receptor for hepatocyte growth factor (HGF). Activation of HGF-c-Met signalling initiates cell invasiveness and triggers metastasis through direct involvement of tumour angiogenesis (Zhang et al, 2003). Upon ligand binding, c-Met activates multiple downstream signal transduction pathways, including the Grb2-Ras-mitogen-activated protein kinase (MAPK) cascade, the phosphatidylinositol-3 kinase (PI3K) pathway, and the signal transducer and activator of transcription (STAT) pathway (Weidner et al, 1993; Furge et al, 2000). c-Met partners include the integrin $\alpha 6 \beta 4, \mathrm{CD} 44$, plexin B, Fas and other RTKs such as RON, EGFR and ErbB2 (Gentile et al, 2008).

c-Met and EGFR are considered to assemble oncogenic signalling networks. Amplified c-Met activates members of the EGFR family and, conversely, mutated or amplified EGFR activates c-Met in vitro (Guo et al, 2008). EGFR is frequently coexpressed with c-Met in cell lines of lung, head and neck, breast, colon, and brain tumours (Reznik et al, 2008).

Enhanced expression of c-Met protein has been described in various solid tumours such as breast cancer (Garcia et al, 2007; 
Eder et al, 2009), oesophageal adenocarcinoma (Herrera et al, 2005), gastric cancer (Drebber et al, 2008; Ji et al, 2008), colon cancer (Liu et al, 1992), lung cancer (Lutterbach et al, 2007; Nakamura et al, 2007), ovarian cancer (Sawada et al, 2007), brain tumour (Kong et al, 2009), hepatocellular carcinoma (Boix et al, 1994; Suzuki et al, 1994), and biliary tract carcinoma (Terada et al, 1998; Hida et al, 1999; Aishima et al, 2002; Nakazawa et al, 2005). Recently, it has been proposed that c-Met might be a promising target for treatment of CC (Socoteanu et al, 2008). However, no study has yet demonstrated its prognostic significance in CC.

To improve our understanding of the clinical significance of c-Met in CC, the primary aim of this study is to clarify the frequency of c-Met overexpression. Following with this analysis, the second aim of this study is to analyse its association with clinicopathological factors, along with molecular data (EGFR, HER2, and VEGF expression), in the largest cohort (111 cases of
IHCC and 136 cases of extrahepatic CC (EHCC)) of surgical specimens of CC. We also examined the expression of c-Met and EGFR in CC cell lines.

\section{PATIENTS AND METHODS}

\section{Patients}

A total of 247 patients with CC were examined in the present study. The patients had undergone surgery and been diagnosed histologically as having adenocarcinoma of the bile duct, except for cancer of gallbladder and ampulla of Vater, at the National Cancer Center Hospital, Tokyo, between February 1990 and July 2005. Patients who had other malignancies or had died within four weeks after surgery were excluded. Clinical and pathological data
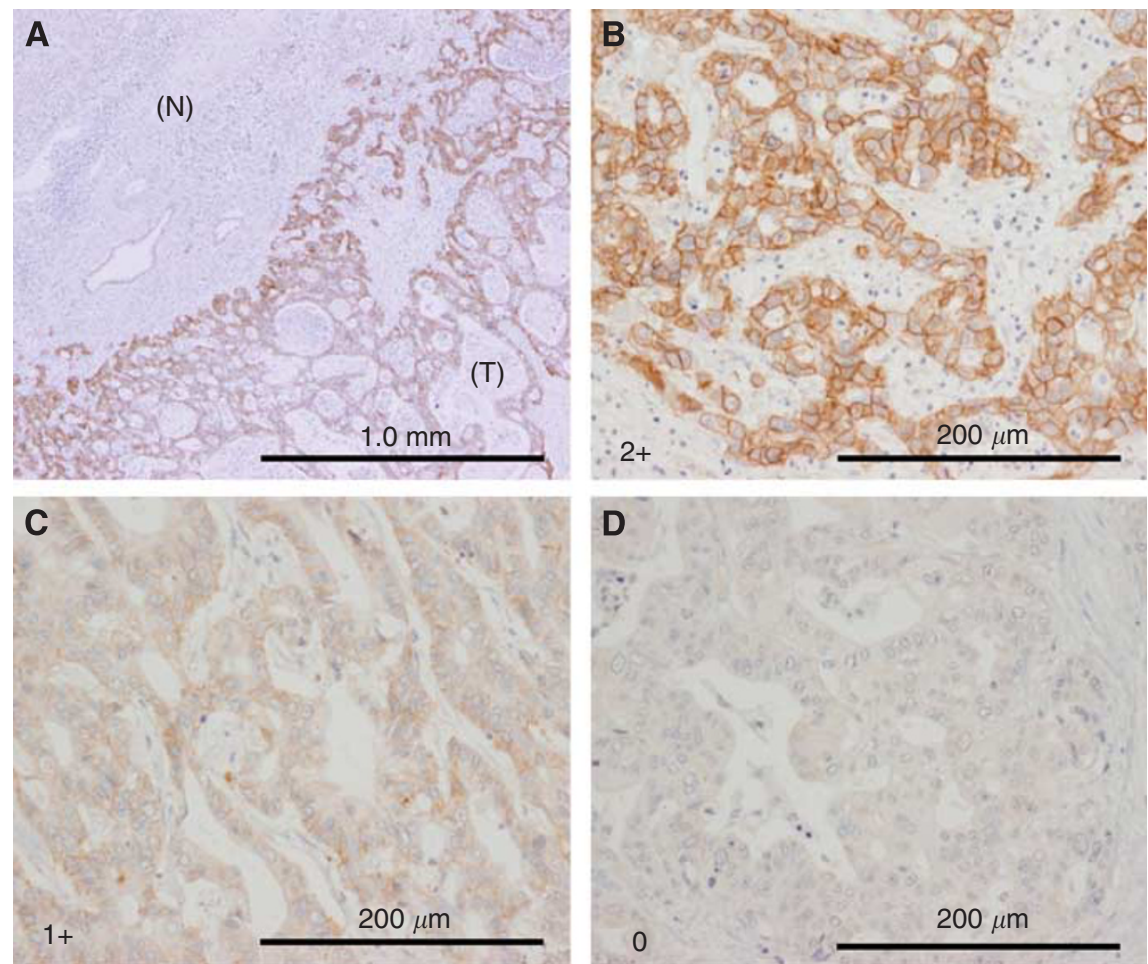

Figure I c-Met expression in primary CC cases. (A) c-MET expression was exclusively detected in tumour cells ( $(T)$, but not in non-cancerous bile duct epithelium (N). (B-D) Representative IHC pictures of higher magnification of c-Met expression (expression score is $2+(\mathbf{B})$, I $+(\mathbf{C})$, and 0 (D), respectively). c-MET is localised in both the cell membrane and cytoplasm of CC cells. Scale bar indicates $1.0 \mathrm{~mm}(\mathbf{A})$ and $200 \mu \mathrm{m}(\mathbf{B}-\mathbf{D})$.
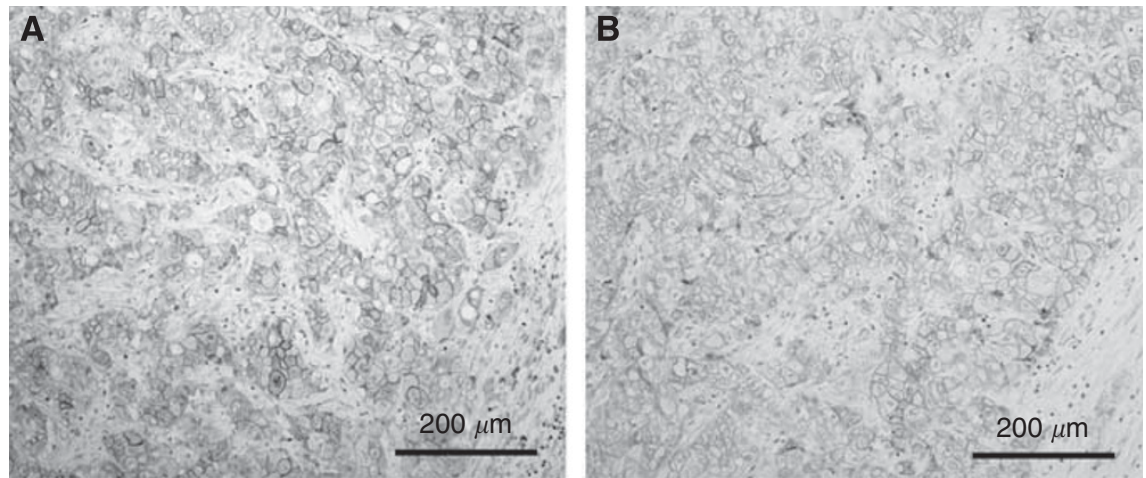

Figure 2 A representative case showing coexpression of c-Met $(\mathbf{A})$ and EGFR $(\mathbf{B})$ in adjacent sections of the same tumour. Scale bar indicates $200 \mu$ m. 
were obtained from the medical records of the patients. To examine the correlations of c-Met with other RTKs (EGFR, HER2, or VEGF), qualified cases including previous data for overexpression of these molecules (Yoshikawa et al, 2008) were examined.

The studied patients included 168 men and 79 women ranging in age from 33 to 82 years (median 65 years), who had been observed for periods ranging from 1.4 to 204.5 months (median 29.8 months). The cases were divided into two groups, IHCC and EHCC, in accordance with the TNM Classification of Malignant Tumours (Sobin and Wittekind, 2002) defined by the Union for International Cancer Control (UICC) and the World Health Organization Histological Classification of Tumours (Hamilton and Altonen, 2000). There were 111 cases of IHCC and 136 cases of EHCC. In this study, peri-hilar EHCC and distal EHCC are combined as EHCC because it is difficult to categorise EHCC based on the origin of the cystic duct. Tumour recurrence was defined as tumour growth in any site of the body after the operation, which was diagnosed clinically, radiologically, or pathologically, but mainly by computed tomography and ultrasonography. Only tumour death was used for analysis. The research protocol was approved by the Ethics Committee of the National Cancer Center, Tokyo, Japan. All patients gave written informed consent for inclusion in this study.

\section{Immunohistochemistry}

Immunohistochemistry (IHC) was performed on 247 formalinfixed, paraffin-embedded tissue sections. Immunohistochemical staining for c-Met was performed using a polymer-based method (Envision + Dual link-system-HRP (Dako, Glostrup, Denmark)).

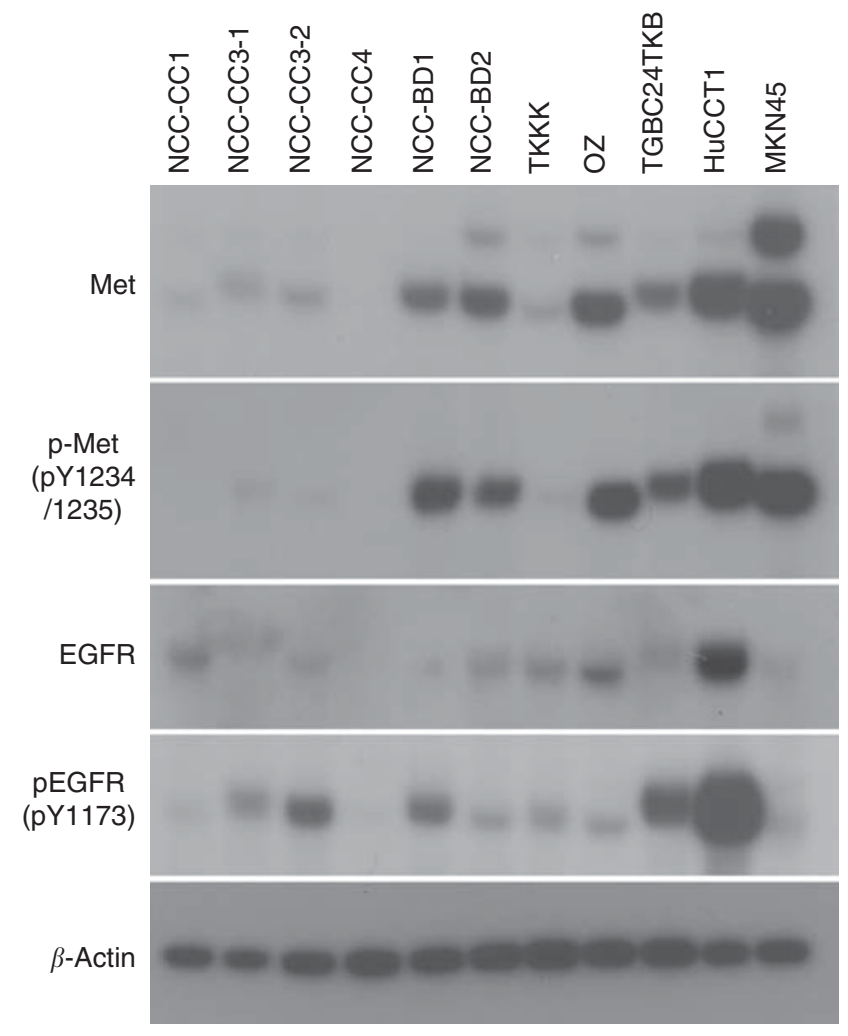

Figure 3 Immunoblot analysis of c-Met, phosphorylated-Met PY 1234/ 1235), EGFR, and phosphorylated EGFR (pY I I73) in CC cell lines. MKN45 cell (a human gastric cancer cell) is a positive control of c-Met and phosphorylated-Met expression (Smolen et al, 2006). $\beta$-actin is a loading control.
Table I Comparison of clinicopathological factors between patients with high and low c-Met expression in IHCC

\begin{tabular}{|c|c|c|c|}
\hline & \multicolumn{2}{|c|}{ c-Met } & \multirow[b]{2}{*}{$P$-value } \\
\hline & High & Low & \\
\hline \multicolumn{4}{|l|}{ Gender } \\
\hline Male & 7 & 59 & 0.7636 \\
\hline Female & 6 & 39 & \\
\hline \multicolumn{4}{|l|}{ Age } \\
\hline$\geqslant 65$ & 9 & 48 & 0.2396 \\
\hline$<65$ & 4 & 50 & \\
\hline \multicolumn{4}{|l|}{ Tumour size } \\
\hline$\geqslant 5 \mathrm{~cm}$ & 8 & 39 & 0.2430 \\
\hline$<5 \mathrm{~cm}$ & 5 & 52 & \\
\hline \multicolumn{4}{|l|}{ Macroscopic type } \\
\hline Mass forming & 10 & 83 & 0.4397 \\
\hline Non-mass forming & 3 & 15 & \\
\hline \multicolumn{4}{|l|}{ Intrahepatic metastasis } \\
\hline Negative & 8 & 70 & 0.5229 \\
\hline Positive & 5 & 28 & \\
\hline \multicolumn{4}{|l|}{ Invasion to hepatic vein } \\
\hline Negative & 5 & 53 & 0.2496 \\
\hline Positive & 8 & 41 & \\
\hline \multicolumn{4}{|l|}{ Invasion to portal vein } \\
\hline Negative & । & 24 & 0.2907 \\
\hline Positive & 12 & 73 & \\
\hline \multicolumn{4}{|l|}{ Lymph node metastasis } \\
\hline Negative & 7 & 57 & 0.7739 \\
\hline Positive & 6 & 41 & \\
\hline \multicolumn{4}{|l|}{ Histopathological classification } \\
\hline Well differentiated & 4 & 21 & 0.5943 \\
\hline Moderately differentiated & 8 & 73 & \\
\hline Poorly differentiated & । & 4 & \\
\hline \multicolumn{4}{|l|}{ UICC $p T$} \\
\hline In situ+ $1+2 a+2 b$ & 4 & 28 & $>0.9999$ \\
\hline $3+4$ & 9 & 70 & \\
\hline \multicolumn{4}{|l|}{ UICC stage } \\
\hline $1+\|$ & 8 & 51 & 0.5680 \\
\hline III+IVA & 5 & 47 & \\
\hline \multicolumn{4}{|l|}{ Lymphatic vessel invasion } \\
\hline Negative & 2 & 37 & $>0.9999$ \\
\hline Positive & 11 & 61 & \\
\hline \multicolumn{4}{|l|}{ Venous invasion } \\
\hline Negative & 1 & 19 & 0.4566 \\
\hline Positive & 12 & 79 & \\
\hline \multicolumn{4}{|l|}{ Perineural invasion } \\
\hline Negative & 4 & 27 & 0.7536 \\
\hline Positive & 9 & 71 & \\
\hline \multicolumn{4}{|l|}{ Hepatic surgical margin } \\
\hline Negative & 9 & 84 & 0.2202 \\
\hline Positive & 4 & 14 & \\
\hline \multicolumn{4}{|l|}{ Bile duct margin } \\
\hline Negative & 10 & 86 & 0.3797 \\
\hline Positive & 3 & 12 & \\
\hline \multicolumn{4}{|l|}{ EGFR expression } \\
\hline Negative & 5 & 72 & 0.0063 \\
\hline Positive & 8 & 21 & \\
\hline
\end{tabular}


Table I (Continued)

\begin{tabular}{lrrr}
\hline & \multicolumn{2}{c}{ c-Met } & \\
\cline { 2 - 3 } & High & Low & P-value \\
\hline VEGF expression & 7 & 51 & \\
$\quad$ Negative & 6 & 42 & 0.5697 \\
$\quad$ Positive & & & \\
HER2 expression & 13 & 92 & \\
$\quad$ Negative & 0 & 1 & \\
$\quad$ Positive & 0.9999 \\
\hline
\end{tabular}

Abbreviations: EGFR = epidermal growth factor receptor; $I H C C=$ intrahepatic $C C$; UICC $=$ Union for International Cancer Control; VEGF = vascular epithelial growth factor.

Serial sections ( $4 \mu \mathrm{m}$ thick) cut from representative paraffinembedded serial tissue slices were prepared on silicone-coated slides for IHC evaluation. Sections cut through the maximum tumour diameter were selected for IHC evaluation. The sections were deparaffinised in xylene, and rehydrated through graded concentrations of ethanol (50-100\%). Endogenous peroxidase activity was blocked by incubation in $0.3 \%$ hydrogen peroxide solution for $30 \mathrm{~min}$. The antigens were retrieved by heating in a pressure cooker at $121^{\circ} \mathrm{C}$ for $10 \mathrm{~min}$ in $0.01 \mathrm{M}$ citrate buffer. The tissue sections were incubated overnight at $4{ }^{\circ} \mathrm{C}$ with anti-c-Met primary antibody (rabbit polyclonal; IBL, Gunma, Japan) at a dilution of $1: 50$. After a washing in PBS, the sections were treated with Envison + Dual link reagent at room temperature for $30 \mathrm{~min}$. 3,3'-Diaminobenzidine tetrahydrochloride was used as the chromogen, and the tissue sections were counterstained with haematoxylin.

Intensities of c-Met immunoreactivity were defined as: 0 , complete absence of membrane staining or membrane staining in less than $30 \%$ of cancer cells; $1+$, faint and partial membrane staining in at least $30 \%$ of cancer cells; $2+$, strong and complete staining in at least $30 \%$ of cancer cells. The cases were divided into two groups, c-Met ${ }^{\text {low }}(0$ or $1+)$ or c-Met ${ }^{\text {high }}(2+)$, for purposes of statistical analysis. The sections were evaluated by three observers, $\mathrm{MM}, \mathrm{HO}$, and TS, without knowledge of the clinical data. $\mathrm{HO}$ and TS are board-certified pathologists. IHC of EGFR and assessment of its expression were done as described previously (Yoshikawa et al, 2008).

\section{Cell lines}

NCC-CC1, NCC-CC3-1, NCC-CC3-2, and NCC-CC4 cells were established from human IHCC, and NCC-BD1and NCC-BD2 from human EHCC, at the National Cancer Center Research Institute (Ojima et al, 2010). TKKK, HuCCT1, OZ, TGBC24TKB, and MKN45 were purchased from RIKEN Bio Resource Center or from the Japanese Collection of Research Bioresources. TKKK, TGBC24TKB, and HuCCT1 were established from IHCC, and OZ was from EHCC. MKN45 was a gastric cancer cell line that was used as a positive control, because of its high expression of c-Met and phospho-Met (Smolen et al, 2006). All of the cell lines had been derived from Japanese patients. The originally established six CC cell lines, HuCCT1 and MKN45 were maintained in RPMI with $10 \%$ bovine serum. TGBC24TKB, TKKK, and OZ were maintained in Dulbecco's modified Eagle medium with $10 \%$ bovine serum.

\section{Western blotting}

Subconfluent cells were lysed at $4{ }^{\circ} \mathrm{C}$ for $30 \mathrm{~min}$ using lysis buffer containing $10 \mathrm{~mm}$ Tris- $\mathrm{HCl}$ (pH 7.5), 1\% Triton X-100, and $150 \mathrm{~mm}$ $\mathrm{NaCl}$ with a complete protease inhibitor cocktail (Roche, Basel, Switzerland) and a phosphate inhibitor cocktail (Nacalai Tesque, Kyoto, Japan). The protein concentration was determined using a
Table 2 Comparison of clinicopathological factors between patients with high and low c-Met expression in EHCC

\begin{tabular}{|c|c|c|c|}
\hline & \multicolumn{2}{|c|}{ c-Met } & \multirow[b]{2}{*}{$>$ P-value } \\
\hline & High & Low & \\
\hline \multicolumn{4}{|l|}{ Gender } \\
\hline Male & 16 & 86 & 0.7914 \\
\hline Female & 6 & 28 & \\
\hline \multicolumn{4}{|l|}{ Age } \\
\hline$\geqslant 65$ & 16 & 59 & 0.1004 \\
\hline$<65$ & 6 & 55 & \\
\hline \multicolumn{4}{|l|}{ Tumour size } \\
\hline$\geqslant 3 \mathrm{~cm}$ & 11 & 63 & 0.8144 \\
\hline$<3 \mathrm{~cm}$ & 10 & 50 & \\
\hline \multicolumn{4}{|l|}{ Macroscopic type } \\
\hline Polypoid & 3 & 19 & $>0.9999$ \\
\hline Non-polypoid & 18 & 91 & \\
\hline \multicolumn{4}{|l|}{ Depth of tumour invasion } \\
\hline Within fm & 2 & 13 & $>0.9999$ \\
\hline Beyond fm & 20 & 101 & \\
\hline \multicolumn{4}{|l|}{ Invasion to hepatic artery } \\
\hline Negative & 21 & 111 & 0.5106 \\
\hline Positive & । & 3 & \\
\hline \multicolumn{4}{|l|}{ Invasion to portal vein } \\
\hline Negative & 20 & 82 & 0.0649 \\
\hline Positive & 2 & 32 & \\
\hline \multicolumn{4}{|l|}{ Lymph node metastasis } \\
\hline Negative & 10 & 65 & 0.3554 \\
\hline Positive & 12 & 49 & \\
\hline \multicolumn{4}{|l|}{ Histopathological classification } \\
\hline Papillary & 4 & 18 & 0.0239 \\
\hline Well differentiated & 2 & 30 & \\
\hline Moderately differentiated & 9 & 55 & \\
\hline Poorly differentiated & 7 & 11 & \\
\hline \multicolumn{4}{|l|}{ Lymphatic vessel invasion } \\
\hline Negative & 2 & 98 & 0.7369 \\
\hline Positive & 20 & 16 & \\
\hline \multicolumn{4}{|l|}{ Venous invasion } \\
\hline Negative & 3 & 18 & $>0.9999$ \\
\hline Positive & 19 & 96 & \\
\hline \multicolumn{4}{|l|}{ Perineural invasion } \\
\hline Negative & 4 & 21 & $>0.9999$ \\
\hline Positive & 18 & 93 & \\
\hline \multicolumn{4}{|c|}{ Dissected periductal structures margin } \\
\hline Negative & 18 & 97 & 0.7480 \\
\hline Positive & 4 & 17 & \\
\hline \multicolumn{4}{|l|}{ Bile duct margin } \\
\hline Negative & 16 & 82 & $>0.9999$ \\
\hline Positive & 6 & 32 & \\
\hline \multicolumn{4}{|l|}{ Invasion to other organ } \\
\hline Negative & 12 & 44 & 0.2363 \\
\hline Positive & 10 & 70 & \\
\hline \multicolumn{4}{|l|}{ EGFR expression } \\
\hline Negative & 12 & 93 & 0.0056 \\
\hline Positive & 9 & 16 & \\
\hline \multicolumn{4}{|l|}{ VEGF expression } \\
\hline Negative & 7 & 46 & 0.4798 \\
\hline
\end{tabular}


Table 2 (Continued)

\begin{tabular}{lrrr}
\hline & \multicolumn{2}{c}{ c-Met } & \\
\cline { 2 - 3 } & High & Low & $>$ P-value \\
\hline HER2 expression & 19 & 100 & \\
$\begin{array}{l}\text { Negative } \\
\text { Positive }\end{array}$ & 2 & 9 & $>0.9999$ \\
\hline
\end{tabular}

Abbreviations: EGFR = epidermal growth factor receptor; $\mathrm{EHCC}=$ extrahepatic CC; $\mathrm{fm}=$ fibromuscular layer; VEGF = vascular epithelial growth factor.

Bio-Rad protein assay kit (Bio-Rad Laboratories, Hercules, CA, USA). Lysates ( $5 \mu \mathrm{g}$ protein per well) were separated by SDSPAGE, then transferred to polyvinylidene difluoride membranes (Millipore, Billerica, MA, USA). The membranes were blocked with $5 \%$ skim milk in PBS for $30 \mathrm{~min}$ and then probed with the following primary antibodies: anti-c-Met (rabbit polyclonal; IBL; $1: 1000$ ), anti-phospho-Met (pY1234/1235, rabbit monoclonal, clone D26; Cell Signaling Technology, Danvers, MA, USA; 1:1000), anti-EGFR (mouse monoclonal, clone 31G7; Zymed, South San Francisco, CA, USA; 1:1000), and anti-phospho EGFR (pY1173, rabbit monoclonal, clone 53A5; Cell Signaling Technology) at $4{ }^{\circ} \mathrm{C}$ overnight. After washing with PBS-Tween $20(0.5 \%)$, the membranes were re-blocked and then incubated at room temperature for $1 \mathrm{~h}$ with horseradish peroxidase-conjugated goat anti-mouse or anti-rabbit antibody at a dilution of $1: 1000$. Following three washes, bands were visualised using the ECL Western Blotting Detection Reagents (GE Healthcare UK Ltd, Buckinghamshire, England). Anti- $\beta$-actin (mouse monoclonal; clone AC-15, Sigma, St Louis, MO, USA) was used as a loading control.

\section{Statistics}

Correlations between the results of IHC and clinicopathological factors were determined by Fisher's exact probability test, except for histopathological classification, which was analysed by $\chi^{2}$-test. Cumulative survival rates and survival curves were calculated by the Kaplan-Meier method, and log-rank test was performed for the comparison of survival curves between low and high groups defied by c-Met expression level. The Cox proportional hazards model was used to estimate the hazard ratio and 95\% confidence interval of each outcome (tumour death and recurrence). Multivariate analysis was performed for factors selected as risk factors by univariate analysis, except for UICC pT and UICC stage, which are composed of other factors. Correlations between the intensity of c-Met and that of EGFR in IHC or Western blotting were determined by Spearman's rank correlation. Statistical analysis was done using the Statview 5.0 statistical software package (Abacus Concepts, Berkeley, CA, USA). The level of significance was set at $P<0.05$.

\section{RESULTS}

\section{Immunohistochemical analysis of c-Met in human CC specimens}

c-Met staining was localised in both the cell membrane and cytoplasm of CC cells (Figure 1). Strong immunostaining for c-Met was apparent at the luminal cell surface of neoplastic glands and ducts of adenocarcinoma. Positive staining for c-Met was demonstrated in $143(57.9 \%, 95 \%$ CI: $51.7-64.1)$ of the 247 cases of CC overall, $50(45.0 \%, 95 \%$ CI: $35.7-54.3)$ of the 111 cases of IHCC, and $93(68.4 \%, 95 \%$ CI: $60.6-76.2)$ of the 136 cases of EHCC; high c-Met expression $(2+)$ was demonstrated in 35
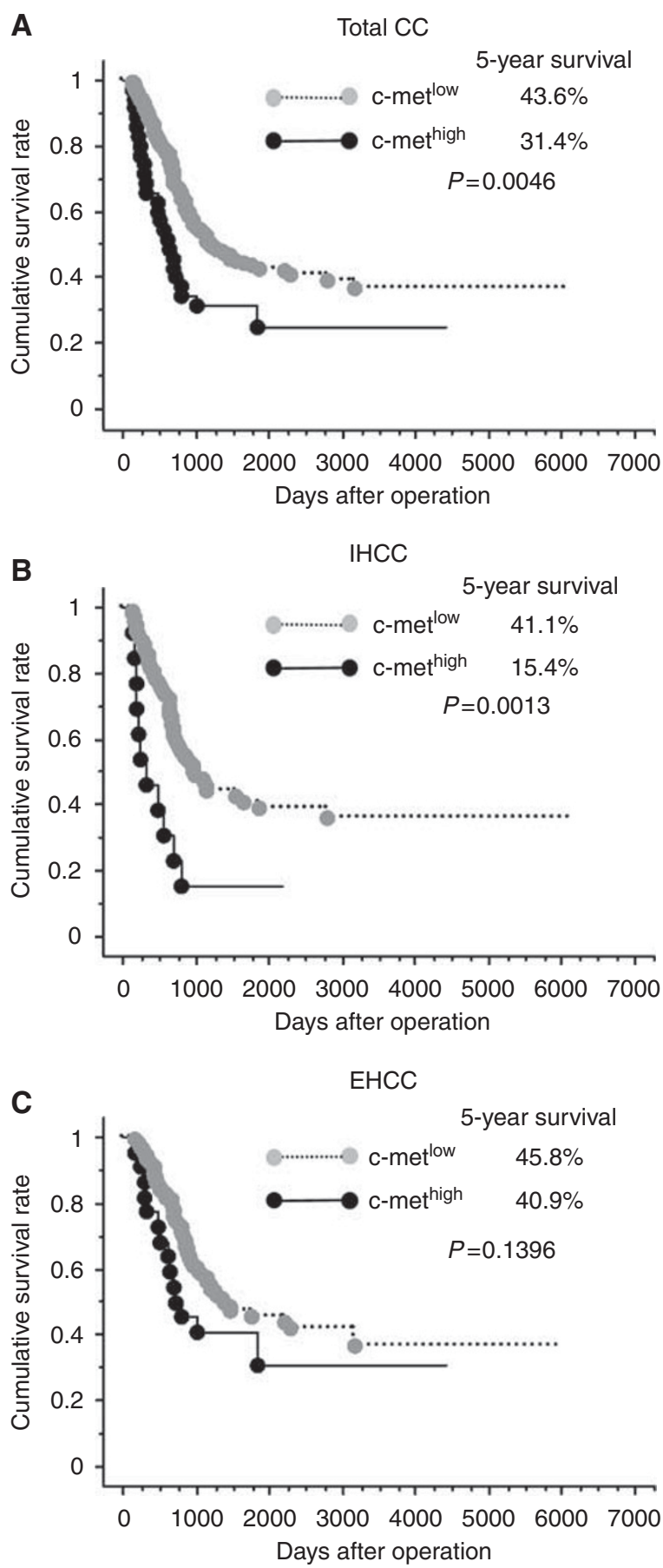

Figure 4 Survival curves according to c-Met expression. High c-Met expression was significantly correlated with poor survival in patients with CC as a whole $(\mathbf{A})$ and in those with intrahepatic CC (IHCC) $(\mathbf{B})$, but not in those with extrahepatic CC (EHCC) $(\mathbf{C})$.

(14.2\%, 95\% CI: $9.8-18.6)$ of the 247 cases of CC overall, 13 $(11.7 \%, 95 \%$ CI: $5.7-17.7)$ of the 111 cases of IHCC, and $22(16.2 \%$, 95\% CI: $10.0-22.4)$ of the 136 cases of EHCC. When compared with EGFR staining, we occasionally observed coexpression of c-Met and EGFR (Figure 2).

\section{c-Met and EGFR expression in CC cell lines}

Expression of c-Met, phospho-Met, EGFR, and phospho-EGFR in ten CC cells and one gastric cancer cells were estimated by 
Western blotting (Figure 3). Expression of c-Met was observed in nine CC cells. Coexpression of c-Met and EGFR was detected in eight of them (except NCC-CC3-1). Prominent c-Met phosphorylation was detected in five cell lines (HuCCT1, OZ, NCC-BD2, TGBC24TKB, and NCC-BD1) and simultaneous activation of c-Met and EGFR was observed in seven cell lines including these five.

\section{Correlations between c-Met and clinicopathological factors}

The relationships between c-Met expression and clinicopathological factors of IHCC and EHCC were evaluated and are shown in Tables 1 and 2. Increased expression of c-Met was significantly correlated with overexpression of EGFR in IHCC $(P=0.0063)$, and histopathological classification $(P=0.0239)$ and overexpression of EGFR $(P=0.0056)$ in EHCC. No other clinical factors were associated with c-Met expression.

Five-year survival for patients in the c-Met ${ }^{\text {high }}$ and $\mathrm{c}-\mathrm{Met}^{\text {low }}$ groups was 15.4 and $41.1 \%(P=0.0013)$ for IHCC and 40.9 and
45.8\% $(P=0.1396)$ for EHCC, respectively (Figure 4). We then performed multivariate analysis to assess the prognostic significance of c-Met expression. In IHCC, the independent predictors of poor overall survival were high c-Met expression (HR:3.92, 95\% CI:1.62 -9.48), macroscopic type (HR:4.57, 95\% CI:1.44-14.51), intrahepatic metastasis (HR:3.27, 95\% CI:1.78-5.99), and lymph node metastasis (HR:1.99, 95\% CI:1.11 -3.59). High c-Met expression (HR:3.50, 95\% CI:1.56 - 7.85), macroscopic type (HR:4.78, 95\% CI:1.69-13.4), intrahepatic metastasis (HR:2.78, 95\% CI:1.604.82), lymph node metastasis (HR:2.94, 95\% CI:1.70 - 5.08), venous invasion (HR:4.62, 95\% CI:1.13-18.8), and EGFR overexpression (HR:1.98, 95\% CI:1.12 -3.51) were significant predictors of diseasefree survival (Table 3 ).

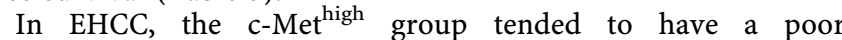
5 -year survival rate, but not to a significant degree. Univariate analysis also showed that $\mathrm{c}-\mathrm{Met}^{\text {high }}$ was not a significant factor for survival. Therefore, multivariate analysis was not performed for EHCC.

Table 3 Multivariate analyses of overall survival and disease-free survival in patients with IHCC. (Cox proportional hazards model)

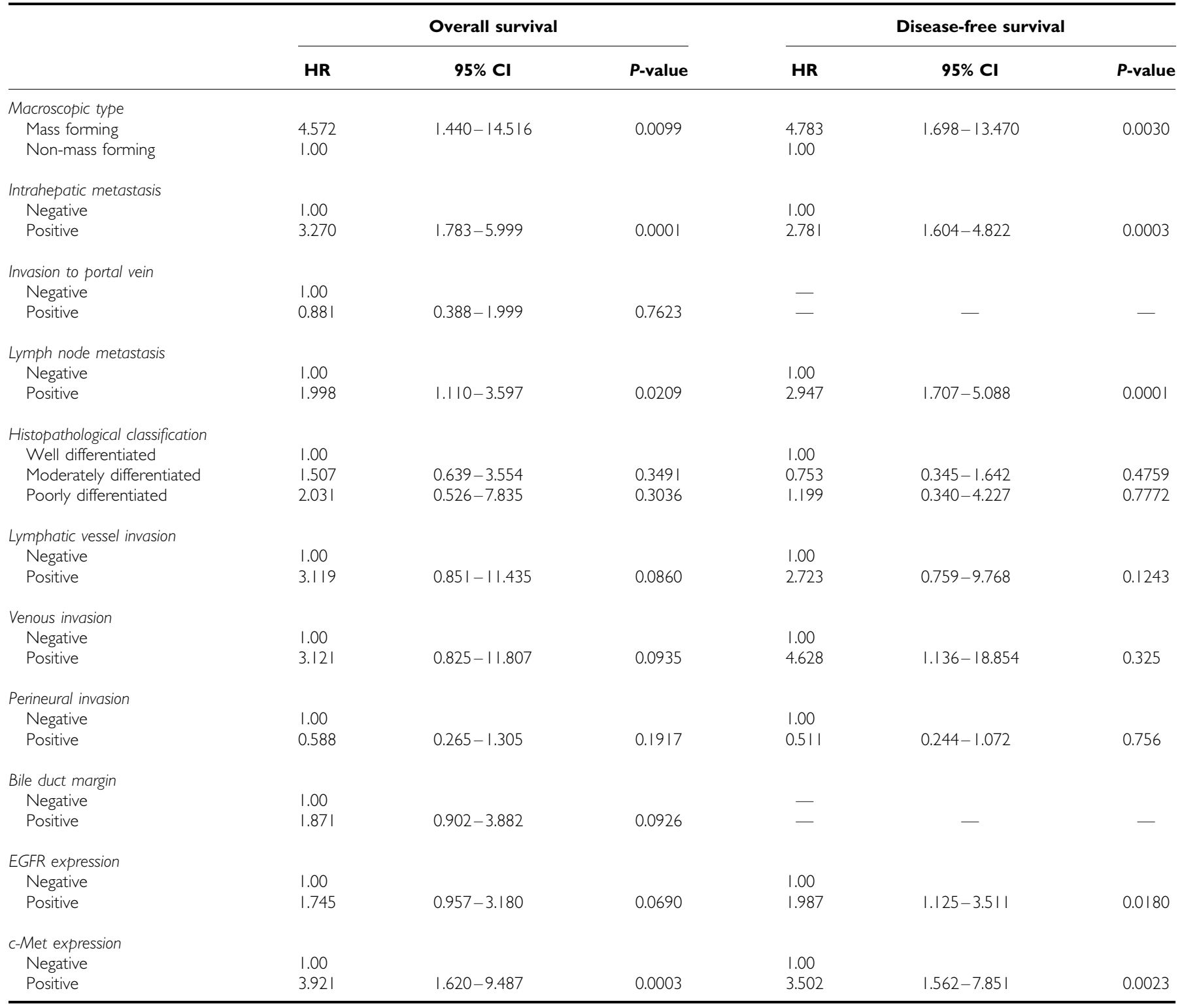

Abbreviations: $\mathrm{Cl}=$ Confidence interval; EGFR = epidermal growth factor receptor; $\mathrm{HR}=$ Hazard ratio; $\mathrm{IHCC}=$ intrahepatic $\mathrm{CC}$. 


\section{DISCUSSION}

In the present study, we have demonstrated the importance of c-Met overexpression in the prognosis and treatment of CC. We found that c-Met expression was correlated with EGFR overexpression in $\mathrm{CC}$, and that it was also a significant prognostic factor in IHCC. In previous studies, the frequency of c-Met overexpression ranged from 21 to $58 \%$ in IHCC (Terada et al, 1998; Aishima et al, 2002; Nakazawa et al, 2005) and from 0 to $80 \%$ in EHCC (Hida et al, 1999; Nakazawa et al, 2005). This rather broad range is probably attributable to the small numbers of cases studied, or to differences in the definition of positivity. Moreover, no correlation between c-Met overexpression and clinical outcome of CC has been demonstrated previously. Here we showed that increased expression of c-Met was significantly associated with decreased overall and disease-free survival in patients with IHCC. The reason why c-Met expression was not a prognostic factor in EHCC may be partly explained by variables associated with their anatomic behaviour and methods of surgery.

Simultaneous expression of c-Met and EGFR has been observed in clinical specimens of primary chordoma (Weinberger et al, 2005) and gastrinoma (Peghini et al, 2002). Accumulated evidence has suggested that cross-talk occurs between c-Met and EGFR in several cancer cell lines (Jo et al, 2000; Farazi et al, 2006; Guo et al, 2008). Here we showed that c-Met expression was correlated with EGFR expression in clinical specimen of CC. We found that both EGFR and c-Met are broadly activated in CC cell lines. Eight CC cells coexpressed both c-Met and EGFR and coactivation of both proteins was detected in seven CC cell lines. It has been proposed that amplified c-Met drives the activity of EGFR family members and that mutated and amplified EGFR can drive c-Met activity

\section{REFERENCES}

Aishima SI, Taguchi KI, Sugimachi K, Shimada M, Sugimachi K, Tsuneyoshi M (2002) c-erbB-2 and c-Met expression relates to cholangiocarcinogenesis and progression of intrahepatic cholangiocarcinoma. Histopathology 40: 269-278

Aljiffry M, Abdulelah A, Walsh M, Peltekian K, Alwayn I, Molinari M (2009) Evidence-based approach to cholangiocarcinoma: a systematic review of the current literature. J Am Coll Surg 208: 134-147

Bergstrom JD, Westermark B, Heldin NE (2000) Epidermal growth factor receptor signaling activates met in human anaplastic thyroid carcinoma cells. Exp Cell Res 259: 293-299

Blechacz B, Gores GJ (2008) Cholangiocarcinoma: advances in pathogenesis, diagnosis, and treatment. Hepatology 48: 308-321

Boix L, Rosa JL, Ventura F, Castells A, Bruix J, Rodes J, Bartrons R (1994) c-met mRNA overexpression in human hepatocellular carcinoma. Hepatology 19: 88-91

Dempke WC, Heinemann V (2009) Resistance to EGF-R (erbB-1) and VEGF-R modulating agents. Eur J Cancer 45: 1117-1128

Drebber U, Baldus SE, Nolden B, Grass G, Bollschweiler E, Dienes HP, Holscher AH, Monig SP (2008) The overexpression of c-met as a prognostic indicator for gastric carcinoma compared to p53 and p21 nuclear accumulation. Oncol Rep 19: $1477-1483$

Eder JP, Vande WGF, Boerner SA, LoRusso PM (2009) Novel therapeutic inhibitors of the c-Met signaling pathway in cancer. Clin Cancer Res 15: $2207-2214$

Farazi PA, Zeisberg M, Glickman J, Zhang Y, Kalluri R, DePinho RA (2006) Chronic bile duct injury associated with fibrotic matrix microenvironment provokes cholangiocarcinoma in p53-deficient mice. Cancer Res 66: $6622-6627$

Furge KA, Zhang YW, Vande WGF (2000) Met receptor tyrosine kinase: enhanced signaling through adapter proteins. Oncogene 19: $5582-5589$

Garcia S, Dales JP, Charafe Jauffret E, Carpentier Meunier S, Andrac Meyer L, Jacquemier J, Andonian C, Lavaut MN, Allasia C, Bonnier P, Charpin C (2007) Overexpression of c-Met and of the transducers PI3K, FAK and JAK in breast carcinomas correlates with shorter survival and neoangiogenesis. Int J Oncol 31: 49-58
(Guo et al, 2008). Mutual or unidirectional interaction between EGFR and MET activation has been reported in several cell lines (Bergstrom et al, 2000; Jo et al, 2000; Reznik et al, 2008). It is thought that either c-Met or EGFR stands at the top of the hierarchy of the downstream signalling pathway governed by the two molecules in a subset of cancer.

Collectively, it seems reasonable that efficient molecular therapy for CC should target multiple kinases such as c-Met, EGFR, and VEGFR. c-Met activation is regarded as one of the molecular mechanisms involved in the acquisition of resistance to anti-EGFR therapy, as activation of the alternative RTK pathway would bypass the EGFR pathway (Dempke and Heinemann, 2009). Therefore, inhibition of c-Met, either alone or in combination with an EGFR inhibitor, may be clinically beneficial in the setting of EGFR inhibitor resistance (Eder et al, 2009). Several studies have focused on combination therapy with c-Met inhibitors and agents targeting EGFR family members (Toschi and Janne, 2008).

In conclusion, c-Met overexpression is significantly correlated with overexpression of EGFR in CC and with prognosis in IHCC. Further molecular investigation of the interaction between EGFR and c-Met in this fatal disease is urgently needed.

\section{ACKNOWLEDGEMENTS}

This work was supported in part by the Foundation for Promotion of Cancer Research (FPCR), Japan, and a grant-in-aid for the Comprehensive 10-Year Strategy for Cancer Control from the Ministry of Health, Labor and Welfare, Japan. MM is a recipient of a Research Resident Fellowship from the FPCR.
Gentile A, Trusolino L, Comoglio PM (2008) The Met tyrosine kinase receptor in development and cancer. Cancer Metastasis Rev 27: $85-94$

Guo A, Villen J, Kornhauser J, Lee KA, Stokes MP, Rikova K, Possemato A, Nardone J, Innocenti G, Wetzel R, Wang Y, MacNeill J, Mitchell J, Gygi SP, Rush J, Polakiewicz RD, Comb MJ (2008) Signaling networks assembled by oncogenic EGFR and c-Met. Proc Natl Acad Sci USA 105: $692-697$

Hamilton SR, Altonen LA (2000) World Health Organization Classification of Tumours: pathology \& Genetics: Tumours of the Digestive System. IARC Press: Lyon

Herrera LJ, El Hefnawy T, Queiroz OPE, Raja S, Finkelstein S, Gooding W, Luketich JD, Godfrey TE, Hughes SJ (2005) The HGF receptor c-Met is overexpressed in esophageal adenocarcinoma. Neoplasia 7: 75-84

Hezel AF, Zhu AX (2008) Systemic therapy for biliary tract cancers. Oncologist 13: $415-423$

Hida Y, Morita T, Fujita M, Miyasaka Y, Horita S, Fujioka Y, Nagashima K, Katoh H (1999) Clinical significance of hepatocyte growth factor and c-Met expression in extrahepatic biliary tract cancers. Oncol Rep 6: 1051-1056

Ji J, Zhao P, Huang B (2008) [Study of gastric carcinoma and PCNA and c-met gene abnormality]. Wei Sheng Yan Jiu 37: 479-482

Jo M, Stolz DB, Esplen JE, Dorko K, Michalopoulos GK, Strom SC (2000) Cross-talk between epidermal growth factor receptor and c-Met signal pathways in transformed cells. J Biol Chem 275: 8806-8811

Kong DS, Song SY, Kim DH, Joo KM, Yoo JS, Koh JS, Dong SM, Suh YL, Lee JI, Park K, Kim JH, Nam DH (2009) Prognostic significance of c-Met expression in glioblastomas. Cancer 115: $140-148$

Liu C, Park M, Tsao MS (1992) Overexpression of c-met proto-oncogene but not epidermal growth factor receptor or c-erbB-2 in primary human colorectal carcinomas. Oncogene 7: 181-185

Lutterbach B, Zeng Q, Davis LJ, Hatch H, Hang G, Kohl NE, Gibbs JB, Pan BS (2007) Lung cancer cell lines harboring MET gene amplification are dependent on Met for growth and survival. Cancer Res 67: $2081-2088$

Mouzas IA, Dimoulios P, Vlachonikolis IG, Skordilis P, Zoras O, Kouroumalis E (2002) Increasing incidence of cholangiocarcinoma in Crete 1992-2000. Anticancer Res 22: 3637 - 3641 
Nakamura Y, Niki T, Goto A, Morikawa T, Miyazawa K, Nakajima J, Fukayama M (2007) c-Met activation in lung adenocarcinoma tissues: an immunohistochemical analysis. Cancer Sci 98: 1006-1013

Nakazawa K, Dobashi Y, Suzuki S, Fujii H, Takeda Y, Ooi A (2005) Amplification and overexpression of c-erbB-2, epidermal growth factor receptor, and c-met in biliary tract cancers. J Pathol 206: 356-365

Ojima H, Yoshikawa D, Ino Y, Shimizu H, Miyamoto M, Kokubu A, Hiraoka N, Morofuji N, Kondo T, Onaya H, Okusaka T, Shimada K, Sakamoto Y, Esaki M, Nara S, Kosuge T, Hirohashi S, Kanai Y, Shibata T (2010) Establishment of six new human biliary tract carcinoma cell lines and identification of MAGEH1 as a candidate biomarker for predicting the efficacy of gemcitabine treatment. Cancer Sci 101: 882-888

Okuda K, Nakanuma Y, Miyazaki M (2002) Cholangiocarcinoma: recent progress. Part 1: epidemiology and etiology. J Gastroenterol Hepatol 17: 1049- 1055

Peghini PL, Iwamoto M, Raffeld M, Chen YJ, Goebel SU, Serrano J, Jensen RT (2002) Overexpression of epidermal growth factor and hepatocyte growth factor receptors in a proportion of gastrinomas correlates with aggressive growth and lower curability. Clin Cancer Res 8: $2273-2285$

Reznik TE, Sang Y, Ma Y, Abounader R, Rosen EM, Xia S, Laterra J (2008) Transcription-dependent epidermal growth factor receptor activation by hepatocyte growth factor. Mol Cancer Res 6: 139-150

Sawada K, Radjabi AR, Shinomiya N, Kistner E, Kenny H, Becker AR, Turkyilmaz MA, Salgia R, Yamada SD, Vande WGF, Tretiakova MS, Lengyel E (2007) c-Met overexpression is a prognostic factor in ovarian cancer and an effective target for inhibition of peritoneal dissemination and invasion. Cancer Res 67: 1670-1679

Smolen GA, Sordella R, Muir B, Mohapatra G, Barmettler A, Archibald H, Kim WJ, Okimoto RA, Bell DW, Sgroi DC, Christensen JG, Settleman J, Haber DA (2006) Amplification of MET may identify a subset of cancers with extreme sensitivity to the selective tyrosine kinase inhibitor PHA665752. Proc Natl Acad Sci USA 103: 2316-2321

Sobin LH, Wittekind CH (2002) TNM Classification of Malignant Tumours, 6th edn. Wiley-Liss/International Union Against Cancer (UICC): New York
Socoteanu MP, Mott F, Alpini G, Frankel AE (2008) c-Met targeted therapy of cholangiocarcinoma. World J Gastroenterol 14: 2990-2994

Suzuki K, Hayashi N, Yamada Y, Yoshihara H, Miyamoto Y, Ito Y, Ito T, Katayama K, Sasaki Y, Ito A et al (1994) Expression of the c-met protooncogene in human hepatocellular carcinoma. Hepatology 20: $1231-1236$

Terada T, Nakanuma Y, Sirica AE (1998) Immunohistochemical demonstration of MET overexpression in human intrahepatic cholangiocarcinoma and in hepatolithiasis. Hum Pathol 29: 175-180

Toschi L, Janne PA (2008) Single-agent and combination therapeutic strategies to inhibit hepatocyte growth factor/MET signaling in cancer. Clin Cancer Res 14: $5941-5946$

Weidner KM, Sachs M, Birchmeier W (1993) The Met receptor tyrosine kinase transduces motility, proliferation, and morphogenic signals of scatter factor/hepatocyte growth factor in epithelial cells. J Cell Biol 121: $145-154$

Weinberger PM, Yu Z, Kowalski D, Joe J, Manger P, Psyrri A, Sasaki CT (2005) Differential expression of epidermal growth factor receptor, c-Met, and HER2/neu in chordoma compared with 17 other malignancies. Arch Otolaryngol Head Neck Surg 131: 707-711

Yachimski P, Pratt DS (2008) Cholangiocarcinoma: natural history, treatment, and strategies for surveillance in high-risk patients. J Clin Gastroenterol 42: 178-190

Yoshikawa D, Ojima H, Iwasaki M, Hiraoka N, Kosuge T, Kasai S, Hirohashi S, Shibata T (2008) Clinicopathological and prognostic significance of EGFR, VEGF, and HER2 expression in cholangiocarcinoma. Br J Cancer 98: 418-425

Yoshikawa D, Ojima H, Kokubu A, Ochiya T, Kasai S, Hirohashi S, Shibata $\mathrm{T}$ (2009) Vandetanib (ZD6474), an inhibitor of VEGFR and EGFR signalling, as a novel molecular-targeted therapy against cholangiocarcinoma. Br J Cancer 100: $1257-1266$

Zhang YW, Su Y, Volpert OV, Vande WGF (2003) Hepatocyte growth factor/scatter factor mediates angiogenesis through positive VEGF and negative thrombospondin 1 regulation. Proc Natl Acad Sci USA 100 $12718-12723$ 